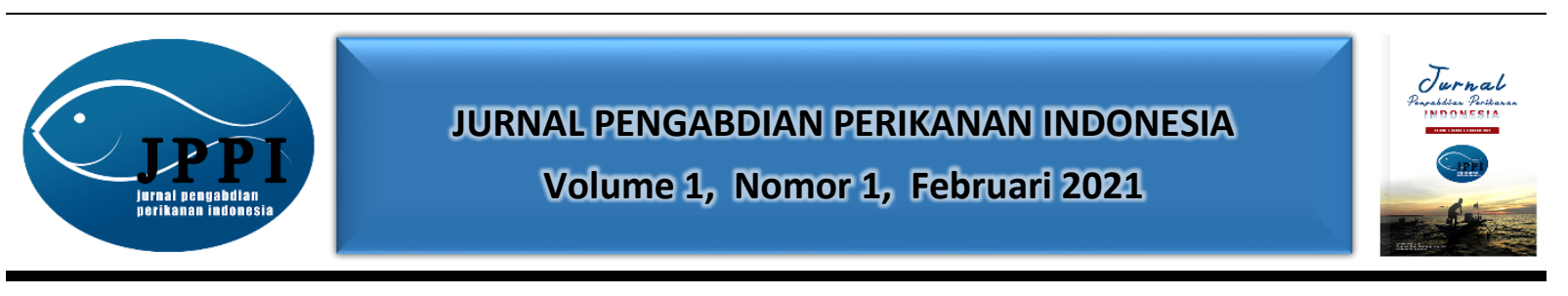

\title{
SOSIALISASI BUDIDAYA CACING SUTRA (TUBIFEX SP.) SEBAGAI PAKAN BENIH IKAN PADA REMAJA KARANG TARUNA DESA GONTORAN, LOMBOK BARAT
}

\section{Dewi Putri Lestari*, Salnida Yuniarti Lumbessy, Dewi Nur’aeni Setyowati, Fariq Azhar}

\author{
Program Studi Budidaya Perairan, Universitas Mataram
}

\author{
*Alamat korespondensi : dewiputrilestari@unram.ac.id \\ (Tanggal Submission: 3 Desember 2020, Tanggal Accepted : 2 Februari 2021)
}

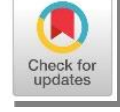

Keyword :
budidaya
cacing sutra,
desa
gontoran

\begin{abstract}
:
Kegiatan pengabdian ini bertujuan untuk memberikan informasi kepada remaja karang taruna Desa Gontoran terkait budidaya cacing sutra (Tubifex sp.). Metode pengabdian menggunakan metode diskusi dan memberikan tayangan video yang berasal dari youtube terkait cara budidaya cacing sutra. Dalam Bahasa Sasak cacing sutra bernama "Longe aiq". Nama lokal ini diperoleh dari hasil diskusi saat sosialisasi. Berdasarkan hasil presentasi dan diskusi dapat diketahui bahwa remaja karang taruna sudah mengetahui dan terbiasa melihat cacing sutra di saluran air yang mengandung bahan organik tinggi. Walaupun demikian, remaja karang taruna belum mengetahui dan melakukan kegiatan budidaya cacing sutra. Pada saat pelaksanaan pengabdian telah diberikan informasi terkait bahan-bahan yang bisa dijadikan sebagai media tumbuh cacing sutra diantaranya dedak, ampas tahu, limbah sayur dengan selalu memanfaatkan limbah lokal. Harapan kedepannya para remaja karang taruna dapat melakukan kegiatan budidaya dengan memanfaatkan juga sumber cacing sutra yang didapatkan dari kawasan Desa Gontoran. Untuk mewujudkan hal tersebut maka diperlukan fasilitas penyediaan wadah budidaya dan pendampingan dalam melakukan kegiatan budidaya cacing sutra.
\end{abstract}

Citati Panduan Sitasi (APPA $7^{\text {th }}$ edition) :

Lestari, D.P., Lumbessy, S.Y., Setyowati, D.N., \& Azhar, F. (2021). Sosialisasi Budidaya Cacing Sutra (tubifex sp.) Sebagai Pakan Benih Ikan Pada Remaja Karang Taruna Desa Gontoran, Lombok Barat. Jurnal Pengabdian Perikanan Indonesia, 1 (1), 7-12. http://doi.org/10.29303/jppi.v1i1.37

\section{PENDAHULUAN}

Desa Gontoran, Kecamatan Lingsar, Kabupaten Lombok Barat memiliki potensi pengembangan komoditas perikanan yang cukup baik. Sebagian warga desa ini sebagai petani pembudidaya ikan. Warga membudidayakan ikan konsumsi di kolam-kolam buatan dan kolam-kolam semen permanen. Pengembangan komoditas ikan konsumsi terutama mendorong berkembangnya usaha perikanan ikan konsumsi di desa Gontoran. Lokasi Desa Gontoran yang dekat dengan sumber mata air membuat para pembudidaya tidak kesulitan untuk memperoleh sumber air. Suplai air di desa Gontoran cukup baik mendukung kegiatan budidaya ikan. Daerah Gontoran juga dilalui oleh aliran sungai yang bisa menjadi sumber cacing sutra (Perda No 8 Tahun 2011).

Pemanfaatan cacing sutra untuk budidaya ikan yang dapat dibudidayakan serta diproduksi secara massal dan mandiri oleh para pembudidaya ikan. Potensi cacing sutera merupakan pakan hidup bagi ikan sangat memungkinkan dikembangkan guna mendukung kebutuhkan pakan alami 
pada kegiatan pembenihan ikan. Habitat yang menjadi kesukaan cacing sutera tumbuh yakni pada tempat atau perairan yang menjadi tempat masuknya air dan media berlumpur dengan tekstur halus.

Oleh karena itu Tim Pengabdian Program Studi Budidaya Perairan Universitas Mataram melakukan sosialisasi Budidaya Cacing sutra dengan memanfaatkan potensi yang ada dari daerah Gontoran. Kegiatan pengabdian pada masyarakat ini diharapkan dapat memberikan informasi terkait budidaya cacing sutra yang dapat dimanfaatkan untuk budidaya benih ikan. Khususnya untuk pemeliharaan ikan cupang.

\section{METODE KEGIATAN}

Kegiatan penyuluhan ini akan dilaksanakan di Desa Gontoran, Kecamatan Lingsar, Kabupaten Lombok Barat. Penyuluhan dilaksanakan dengan menyampaikan informasi kepada masyarakat tentang pengembangan budidaya cacing sutera. Metode yang digunakan dalam penyuluhan ini adalah Focus Group Discusion (FGD) dengan memberikan informasi atau wawasan kepada pembudidaya. Metode penyampaian materi kegiatan pengabdian ini dengan memberikan materi berupa video tayangan yang di download melalui youtube.

\section{HASIL DAN PEMBAHASAN}

Kegiatan Pengabdian Budidaya Cacing Sutra system apartemen melibatkan remaja karang taruna di Desa Gontoran, Kecamatan Lingsar, Lombok Barat. Pemilihan Peserta remaja karang taruna disebabkan oleh dengan adanya kegiatan sampingan budidaya cacing sutra dapat menambah pengetahuan dan kretaifitas remaja karang taruna. Informasi ini didapatkan pada saat audiensi sebelum melakukan kegiatan pengabdian. Karang Taruna adalah organisasi sosial kemasyarakatan sebagai wadah dan sarana pengembangan setiap anggota masyarakat yang tumbuh dan berkembang atas dasar kesadaran dan tanggung jawab sosial dari, oleh dan untuk masyarakat terutama generasi muda di wilayah desa/kelurahan terutama bergerak di bidang usaha kesejahteraan sosial (Peraturan Menteri Sosial RI nomor: 77/HUK/2010 TENTANG PEDOMAN DASAR KARANG TARUNA). Pemilihan remaja karang taruna disebabkan oleh alumni Program Studi Budidaya Perairan yang bernama Lutfi Hamzan Wari merupakan ketua Karang Taruna Desa Gontoran. Sehingga kesempatan tersebut juga menjadi kesempatan bagi tim pengabdian untuk memberikan informasi terkait Budidaya Cacing Sutra Kepada Remaja Karang Taruna.

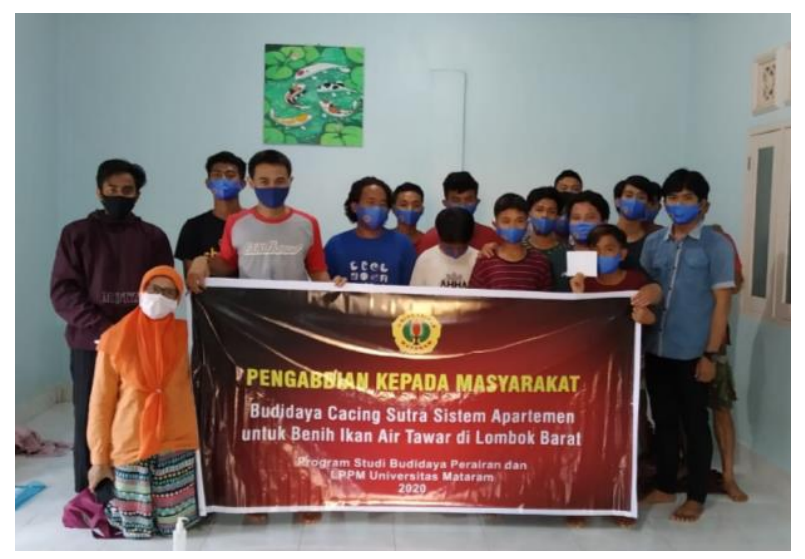

Gambar 1. Tim Pengabdian bersama Remaja Karang Taruna

Sebelum mengaplikasi kegiatan budidaya cacing sutra system apartemen Tim pengabdian melakukan FGD (Focus Grup Discussion). Focus Group Discussion/FGD atau diskusi kelompok terfokus merupakan suatu metode pengumpulan informasi. Pada saat tim pengabdian melakukan 
FGD dengan melibatkan sekitar 20 remaja karang taruna. Pada Saat FGD berlangsung tim pengabdian memberikan tayangan video bagaimana budidaya cacing sutra yang sudah banyak dilakukan oleh pembudidaya di daerah lain.Video yang ditayangkan didapatkan melalui youtube. Setelah melihat tayangan budidaya cacing sutra selanjutnya dilakukan lah diskusi antara peserta dengan tim pengabdian.

Didapatkan informasi bahwa remaja karang taruna sudah mengetahui apa itu cacing sutra. Cacing sutra atau biasa masyarakat lokal menyebutnya "LONGE AIK" atau cacing air. Remaja karang taruna biasanya menemukannya di kali atau parit yang kaya bahan organic dan banyak di jumpai di daerah gontoran. Informasi ini didapatkan dari diskusi yang dilakukan tim pengabdian bersama dengan peserta. Tetapi untuk budidaya cacing sutra belum pernah sama sekali dilakukan dikawasan gontoran. Ada salah satu peserta bernama Hipzil Lisan Pernah melakukan budidaya cacing tanah yang tujunnya untuk umpan memancing. Peserta tersebut juga mengatakan bahwa cacing membutuhkan bahan organic untuk media pertumbuhannya. Pendapat peserta FGD sesuai dengan pernyataan (Ansyari dan Rifa'l, 2005) yang mengatakan Faktor - faktor penentu dalam keberhasilan budidaya Cacing Sutera antara lain; media budidaya Cacing Sutera, proses fermentasi bahan organik.

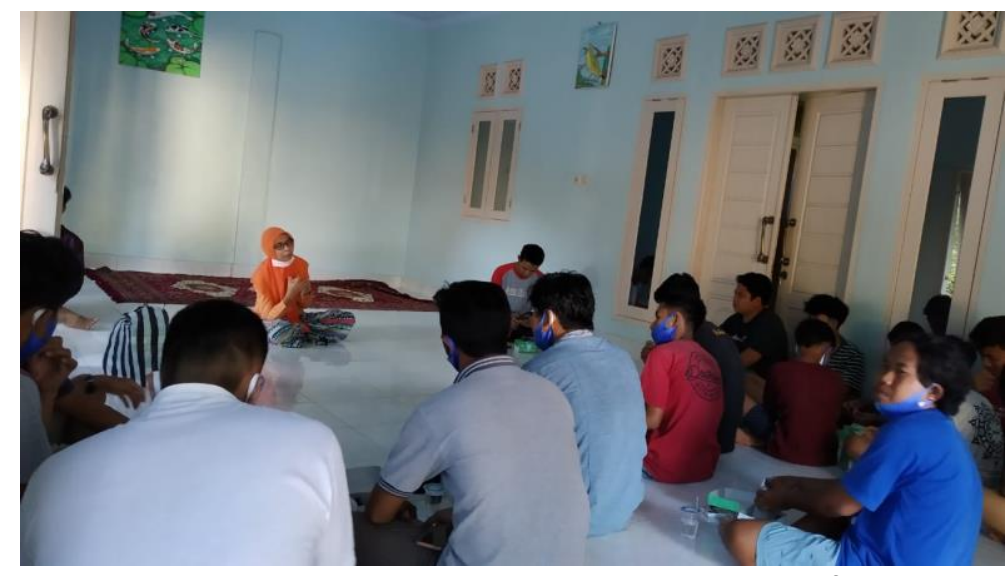

Gambar 2. Kegiatan Diskusi dan Sharing Informasi

Kegiatan budiaya cacing sutra ini diawali dengan membuat contoh sampel pembuatan media untuk hidupnya cacing sutra dengan memanfaatkan bahan yang mudah ditemui disekitaran lingkungan yaitu limbah rumbah tangga. Alat yang digunakan adalah ember, pisau untuk mencacah, karung sebagai alas. Bahan yang digunakan adalah sayur-sayuran yang dibeli di pasar, dedak, dan ampas tahu. Budidaya cacing sutera membutuhkan substrat yang kaya akan bahan organic sebagai makanan bagi cacing. Kotoran ayam, ampas tahu dan ampas arak merupakan limbah organik yang dapat digunakan sebagai suplai makanan untuk menopang pertumbuhan cacing sutera. Pemanfaatan limbah organik dapat meminimalisir biaya untuk membeli bahan baku produksi (Sugiura, et al., 2009).

Proses pembuatan media budidaya cacing sutra Media pemeliharaan yang digunakan adalah lumpur yang diambil disekitaran sungai desa gontoran yang aliran sungainya tidak tercemar sebagai substrat dan kotoran ayam, ampas tahu, dan ampas arak sebagai bahan organik yang berfungsi sebagai asupan nutrisi cacing. Menurut Nurfitriani, et al. (2014), kotoran ayam termasuk bahan organik yang mudah larut dalam air dan memiliki kandungan nitrogen tinggi yaitu 2,94\% sehingga dapat meningkatkan nutrisi tanah, nutrisi yang ada di tanah ini kemudian dimanfaatkan oleh cacing 
sutera untuk tumbuh dan berkembang biak. Menurut Nurfitriani, et al.(2014) bahan organik yang digunakan difermentasi terlebih dahulu dengan menggunakan EM4. Aktivasi EM4 dilakukan dengan cara mencampurkan EM4, gula dan air dengan perbandingan 1:1:50. Pertama-tama, gula dan air dicampur terlebih dahulu sehingga terbentuk larutan. Selanjutnya, dimasukkan EM4 dengan dosis yang setara dengan gula.

Kemudian mengaduk larutan tersebut sampai merata, di mana $1 \mathrm{ml}$ EM4 dapat digunakan untuk fermentasi $1 \mathrm{~kg}$ bahan organik. Selanjutnya adalah pencampuran larutan dengan bahan organik. Bahan yang sudah dicampur tersebut dimasukkan ke dalam plastik berwarna hitam dan ditutup selama 5 hari (Nurfitriani, et al., 2014).

Penebaran awal meliputi penebaran media awal serta penebaran cacing. Pertama tama, lumpur sebagai substrat ditambah dengan bahan organik berupa kotoran ayam, ampas tahu dan ampas arak dicampur dengan perbandingan 1:1 antara substrat dan bahan organik ( $2 \mathrm{~L}$ substrat dan $2 \mathrm{~L}$ bahan organik). Komposisi bahan organik merupakan kombinasi dari beberapa jenis bahan organik yang terdiri dari ampas tahu, ampas arak dan kotoran ayam. Selanjutnya substrat dan bahan organik diaduk secara merata dan didiamkan selama 10 hari sambil dialiri dengan air bersih (Akbar, et al., 2017). Persiapan bahan organik dilakukan dengan cara mencampur bahan organik sesuai dengan dosis bahan organik tiap perlakuan, namun tanpa ada penambahan tanah parit pembuangan. Menurut Hadiroseyani, et al. (2007) pada saat penambahan bahan organik, aliran air pada wadah dihentikan terlebih dahulu kemudian bahan organik ditebar secara merata dan dibiarkan. Setelah 15 menit, aliran air diaktifkan kembali.

Kegiatan budidaya cacing sutera ini menggunakan sistem resirkulasi tertutup yang artinya air yang terpakai dipergunakan kembali. Tujuan dari sistem ini adalah untuk mengurangi penggunaan sumberdaya air dan lahan yang terbatas. Air yang digunakan tetap dilakukan pergantian setiap 10 hari dengan sekaligus membersihkan bak filter. Selain itu, juga dilakukan penambahan air secara rutin setiap 3 hari, karena air tetap mengalami pengurangan akibat dari penguapan. Debit air diatur menggunakan klep dengan kecepatan 0,5 L/menit menurut Febrianti (2004).

Dukungan fasilitas wadah budidaya dari Tim Pengabdian Sumber Dana PNBP 2020 Universitas Mataram berupa wadah yang dapat di manfaatkan untuk kegiatan budidaya cacing sutra juga sudah diberikan melalui ketua karang taruna Desa Gontoran. Dlharapkan dengan adanya fasilitas wadah budidaya tersebut remaja karang taruna dapat memanfaatkan dengan baik dan melakukan kegiatan budidaya cacing sutra sesuai dengan informasi yang sudah diberikan pada saat FGD berlangsung. Karena dari hasil diskusi pada saat FGD kelompok karang taruna meminta adanya fasilitas dukungan yang tidak hanya sosialisasi budidaya cacing sutra saja. Oleh sebab itu tim pengabdian memberikan fasilitas wadah budidaya cacing sutra sebagai bentuk fasilitas yang diharapkan keberlangsungsungan kegiatan budidaya cacing sutra dapat terjadi. Pengaturan wadah sesuai dengan penelitian Akbar et al (2017) Wadah budidaya dipasang dalam sebuah rak kayu dengan bentuk bertingkat layaknya anak tangga. Kemudian disusun dari tinggi ke rendah sehingga air dapat mengalir dari wadah yang paling tinggi ke wadah lainnya yang berada lebih rendah. Tiap wadah dilengkapi dengan saluran pengeluaran air yang pada akhirnya menuju ke bak filter. Bak filter terdiri dari 1 buah terbuat dari kaca yang diberi sekat, kemudian menyusun pasir, kerikil, pecahan karang, serta busa sebagai penyaring air budidaya. Bak filter memiliki ruang yang berfungsi sebagai penampungan air yang telah tersaring kemudian disedot menggunakan pompa menuju ke dalam wadah budidaya cacing. 


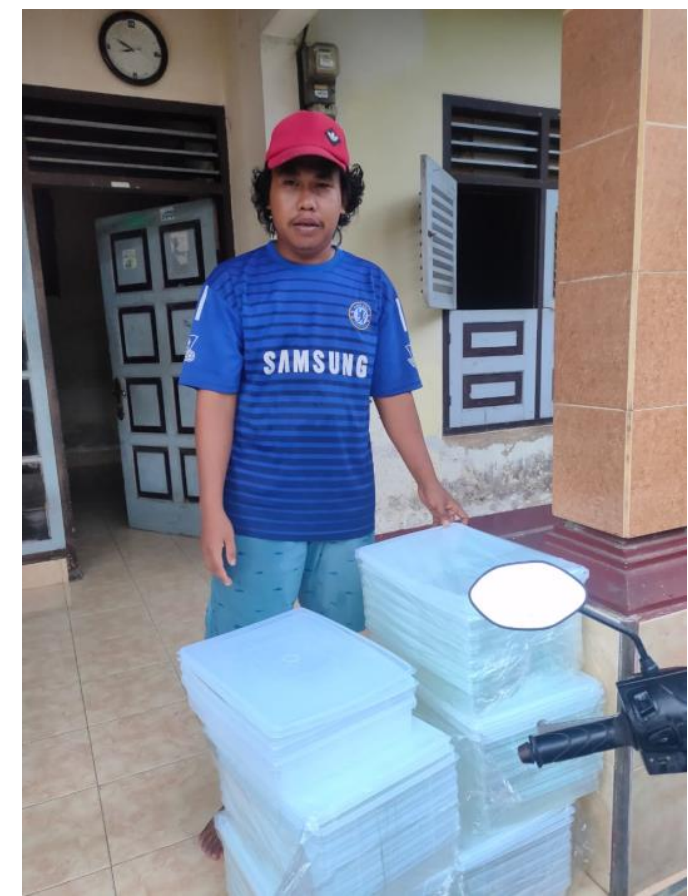

Gambar 3. Penyerahan wadah Budidaya Cacing Sutera

Hasil FGD yang dilakukan mengkasilkan data berupa data kualitatif yang dianalisis menggunakan metode content analysis atau analisi isi dari hasil pengumpulan data yang selanjutnya dibahas sebagai laporan hasil kegiatan pengabdian kepada masyarakat. Tim pengabdian akan tetap melakukan monitoring dan evaluasi sebagai wujud dukungan terhadap mitra dalam keberlanjutan kegiatan pengabdian ini. Monitoring dan evaluasi dapat dilakukan dengan melakukan kunjungan langsung ataupun meminta ketua karang taruna memberikan foto atau video pelaksanaan budidaya cacing sutra.

\section{KESIMPULAN DAN SARAN}

\section{Kesimpulan}

1. Melalui kegiatan FGD remaja karang taruna sudah mengetahu informasi terkait budidaya cacing sutra

2. Pemberian fasilitas wadah budidaya cacing sutra oleh tim pengabdian diharapkan mampu meningkatkan minat remaja karang karang taruna untuk melakukan kegiatan budidaya cacing cacing sutra

3. Diharapkan pula dengan adanya budidaya cacing sutra dapat meningkatkan keterampilan remaja karang taruna dan dapat menjadi sumber penghasilan tambahan.

\section{Saran}

1. Tetap Perlu adanya monitoring oleh tim pengabdian untuk keberlanjutan kegiatan budidaya cacing sutra

2. Tim pengabdian memberikan informasi-informasi terbaru terkait budidaya cacing sutra

\section{UCAPAN TERIMA KASIH}

Penulis mengucapkan terimakasih kepada Lembaga Penelitian dan Pengabdian Kepada Masyarakat Universitas Mataram yang telah memberi dukungan financial terhadap kegiatan pengabdian kepada masyarakat ini. 


\section{DAFTAR PUSTAKA}

Akbar, L.P.F., W.H. Muskita., dan M. Idris. 2017. Pengaruh Substrat Media Terhadap Biomassa Cacing Sutera (Tubifex sp.) yang Dibudidayakan dengan Sistem Resirkulasi Tertutup. Media akuatika. 2 (2) : 337-346

Ansyari, P. dan Rifa'i, A.M. 2005. Penggunaan Berbagai Dosis Pupuk Pelengkap Cair (PPC) Bioton untuk Pertumbuhan Populasi Cacing Sutera (Tubifex sp). Jurnal Agroscientiae. 5 (12) 25-32

Febrianti, D. 2004. Pengaruh Pemupukan Harian dengan Kotoran Ayam Terhadap Pertumbuhan Populasi dan Biomassa Cacing Sutera (Limnodrillus). Skripsi. Program Studi Teknologi dan Manjemen Akuakultur. Fakultas Perikanan dan IImu Kelautan. Institut Pertanian Bogor. 46 hal

Hadiroseyani, Y., Nurjanah, Wahjuningrum, D. 2007. Kelimpahan bakteri dalam budidaya cacing Limnodrilus sp. Yang dipupuk kotoran ayam hasil fermentasi. Jurnal Akuakultur Indonesia, 6(1):79-78.

Nurfitriani, L., Suminto, Hutabarat, J. 2014.Pengaruh penambahan kotoran ayam, ampas tahu dan silase ikan rucah dalam media kultur terhadap biomassa, populasi dan kandungan nutrisi cacing sutera (Tubifex sp.). Journal of Aquaculture Management and Technology, 3(4):109-117

Peraturan Daerah Kabupaten Lombok Barat Nomor 8 Tahun 2011 Tentang Penetapan Desa Persiapan Menjadi Desa Di Kabupaten Lombok Barat. 